No. 24, February 1964

\title{
光イオン化および極微量試料用質量分析計（I） 静作動ならびに真空特性
}

\author{
A Mass Spectrometer for Photo-Ionization and Microanalysis \\ Characteristics of Static Operation and Vacuum
}

( I )

\author{
杉浦俊男*・井上嘉徳*・外山、修*・早川晃 雄** \\ 岡 本 潤 一***・野田保 $* * * *$ \\ Toshio Sugiura, Yoshinori Inoue, Osamu Toyama, Teruo Hayakawa, \\ Junichi Okamoto and Tamotsu Noda
}

(1964年 1 月20日受理)

\begin{abstract}
A mass spectrometer for photo-ionization by vacuum ultra-violet light and for microanalysis by static operation was constructed in University of Osaka Prefecture. The analyser tube and ion source can be baked out up to about $400^{\circ}$ and $300^{\circ} \mathrm{C}$, respectively. The other parts of the mass spectrometer can be baked out at about $130^{\circ} \mathrm{C}$. By total 250 hours' baking out and evacuation end vacuum reached to $2 \times 10^{-9} \mathrm{mmHg}$, and almost no background peak was detected under dynamic operation by an usual type d.c. amplifier. When static operations were carried out under these experimental conditions, main residual gases of hydrogen, methane and carbon monoxide increased for the duration of static operation. The evacuation rates by the Bayard-Alpert type ionization gauge were measured for hydrogen, methane, carbon monoxide, carbon dioxide, argon, neon and helium. The results indicate that the evacuation rates of hydrogen and methane by the Bayard-Alpert type ionization gauge are considerably large, and that the evacuation rates of noble gases have correlation to their ionization probabilities. The sensitivities in item of $\mathrm{A} / \mu \mathrm{cc}$ NTP of noble gases for analysis by static operation were measured, and the results show that the sensitivities $(\mathrm{A} / \mu \mathrm{cc}$ $\mathrm{NTP})$ of ${ }^{40} \mathrm{Ar},{ }^{20} \mathrm{Ne}$ and ${ }^{4} \mathrm{He}$ are $6.39 \times 10^{-13}, 1.26 \times 10^{-13}$ and $6.92 \times 10^{-14}$, respectively. Further measurements using a $\mathrm{Cu}-\mathrm{Be}$ twelve-stage secondary electron multiplier have been continued.
\end{abstract}

\section{1. 緒言}

本装置は其空紫外部の単色光に上る光電離機構, イ オン化電圧および出現電生の測定, イオンの単分子解 離反応等の諸研究のほか, 静作動による極微量気倈試

* 大阪府立大学工学部灾用化学教室（堺市百毛自梅町 4 丁）

Department of Applied Chemistry, College of Engineering,

University of Osaka Prefecture (4-cho, Mozu-Umemachi, Sakai, Osaka).

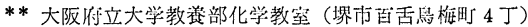

Department of Chemistry, College of General Education, University of Osaka Prefecture (4-cho, Mozu-Umemachi, Sakai, Osaka).

*** 日立製作所中央研究所 (菆尔都北多摩郡国分寺町) Hitachi Central Research Laboratory (Kokubunji-machi, Kitatama-gun, Tokyo).

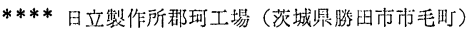
Naka Works, Hitachi Ltd. (Ichige-cho, Katsuta, Ibarakiken).
料（主に稀ガス）の分析を目的として，文部省機関研 筞費, 大阪府の研究助成金ならびに日立製作所中央研 労所および同社那珂工場の協力を得て1960年に大阪府 立大学任設置された。設置以来, 極微量試料用質量分 析計としての真空および静作動特性の測定, 光イオン 化買量分析計としての光源部の製作，モノクロメータ 一部の真空特性の测定，光軸の調整等を行なってきた が，本報には極微量試料用質量分析計としての其空お よび静作動の諸特性を竍告する。

一般に，質量分析計のイオン源内で起る諸過程の研 笲においては，イオン源内における試料気体の密度を 知るととがしばしば必裂となる。たとえば，イオン化 過程の研笲においてはイオン化断面積を求めるために イオン源内の試料気体の压力を知る必袈がある。この ような必要性にもかかわらず，イオン源内に拈ける気 
本心王力について正確な和見をうるととは従来困難と されており，多くは分析管内の其空度加ら推定した师

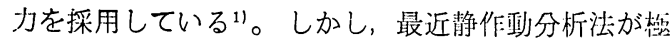
微量試料（主として稀ガス同位体）の分析を目的とし て開発されてきた2(314)51。乙れによれば，イオン源を 含めた分析管内に気体を封じ込めてイオン電流を検出 するので，一定のイオン電流を検出するに必要なイオ ン源内の気体の压力は直接測定された分析管内の殴力 と等しい。したがって，動作動分析の場合のガス溜の 玨力とイオン電流の関係があれば，イオン電流が導入 気体の政力に比例する圧力籁囲においては，イオン源 内の気体の压力を比較的正確に求めるととができる。 また, 炭化水蒵の静作動分析は，イオン源の電子衝軗 によるイオン吸着作用，分析管への吸着作用等のため に困難と思狆れるが，ての場合にあ稀ガスでの静作動 分析の結果とイオン化能率を比較して，イオン源内の 圧力を求めることができる。

以上を考虑して，本装置では，単色光計を取りはず
すととにより，静作動分析および焼出し可能のための Hintenberger 式金属兵空バルブを具えた極微量試料 用啠量分析計として使用しうるよう設設計されている。 本機の動作動時における到達尖空度は $2 \times 10^{-9} \mathrm{mmHg}$ に達し，静作動状態では 1 洔間以上 $10^{-7} \mathrm{mmHg}$ の年! 空度を保つととができた。また，静作動時における残 留気体（不鉟鋼加らの放出気体）の主なすのは， $\mathrm{H}_{2}$, $\mathrm{CO}, \mathrm{CH}_{4}$ 等であるととが明かとなった。术報におい ては主として静作動時におけるバックグラウンドの焼 出し時間による影嘅，静作動分析による感度すなわち 分析に必要な試料量の測定，およびイオン源内の気体 任力とイオン電流の関係について献告し，あわせて種 々の気体の電離装空計による排気作用の測定結果を紹 介する。

\section{2. 装置}

\section{$2 \cdot 1$ 装置の 概 要}

光イオン化質量分析計の構成略図を Fig. 1 亿示し

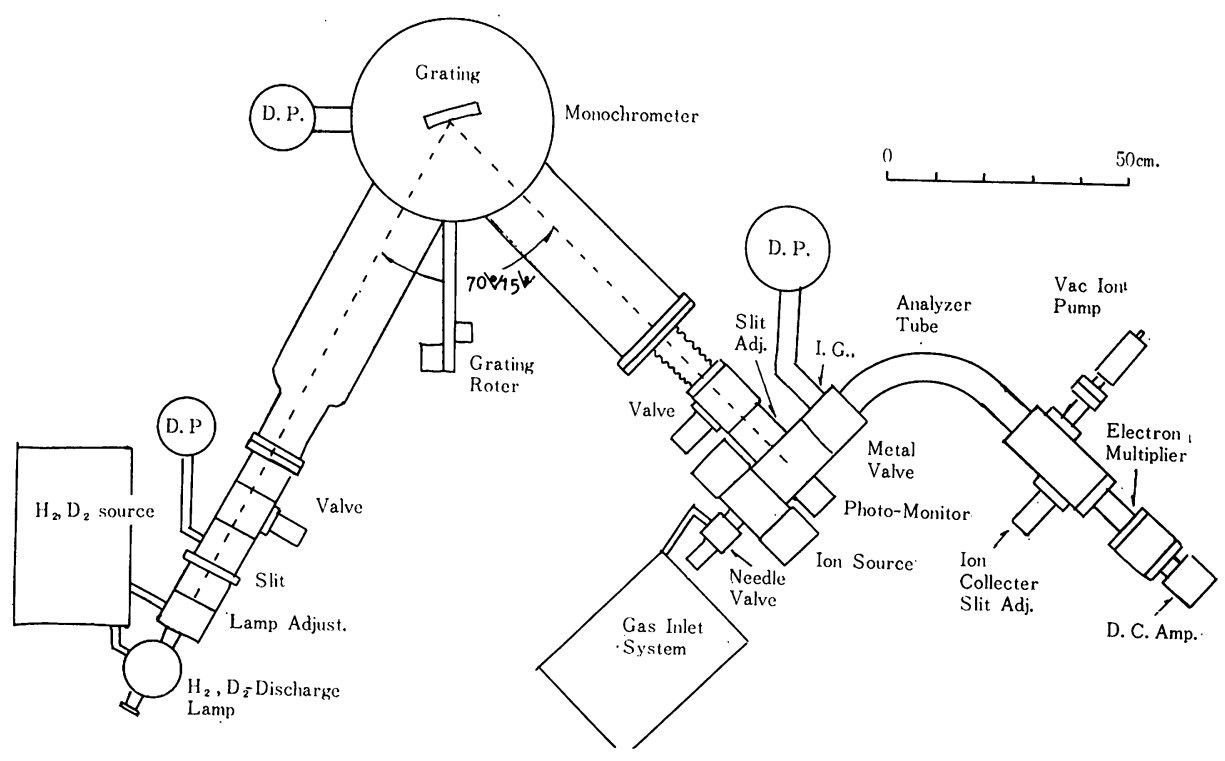

Fig. 1. Schematic arrangement of the mass spectrometer for photo-ionization and microanalysis in University of Osaka Prefecture.

た。本研觉では単色光部部を野昷分析㖕から切り離し て使用しているので，本報では単色光計部その他の光 イオン化に関係ある部分には触れない。質量分析計は

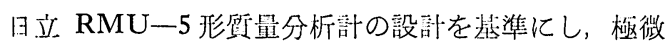
量気体試料測定の目的に合打せて以下に示す改良を行 なった。改良点のうち，主排気系, Hintenberger 式 主バルブ，各電源部は阪大極徴試料用斦量分析部 ${ }^{4}$ の 設㵈に從った。

\section{$2 \cdot 2$ 分 析 部 \\ $2 \cdot 2 \cdot 1$ 分 析 管}

分析管はイオン軌道半径 $200 \mathrm{~mm}, 90^{\circ}$ 型水半設置 で総ステンレス製である。分析管の䋨曲部分の断面は 日立 RMU一5 形と同じく $12 \mathrm{~mm} \times 60 \mathrm{~nm}$ であり, 排気はイオン源側の 4 时油㧩散ポンプおよび回転ポン プによる主排気のみを奖験に使用した。水研觉には使 用しなかったが，Fig. 1 に見るようにコレクター伶 
から Vac Ion ポンプ（日本㽭気製，81/sec）が取り つけられるようになっている。

\section{$2 \cdot 2 \cdot 2$ フランジとガスケット}

本装置に使用されているフランジは, $35 \mathrm{~mm}$ 付 1 ケ 所, $70 \mathrm{~mm}$ 角10个所, $98 \mathrm{~mm}$ 角 5 ケ所であり，そ机ぞ れ $25 \mathrm{~mm} \phi, 50 \mathrm{~mm} \phi, 70 \mathrm{~mm} \phi$ のアルミニウムガスケ ットを使用した。フランジ接触面の形状は, 本体側は 平面, フランジ側は巾 $1.7 \mathrm{~mm}$, 高さ $1.2 \mathrm{~mm}$ の長方 形断面を持つ问筒形突起となっている。また，ガスケ ットの固定のためにガイドを設けた。

ガスケットのアルミニウムは $99.7 \%$ の純度のもので, $0.2 \mathrm{~mm}$ および $0.3 \mathrm{~mm}$ 厚の板から拔型で切り出し, 表面は酸化クロームを使用してパフをかけ, ベンゼン
で洗浄した。比較的力のかけにくい部分のガスケット には $0.3 \mathrm{~mm}$ 厚のあのを使用した。フランジ部に㑺が あるか内至は異物が狭まっているようなととがないか ぎり, 具空洩机はなかった。

\section{$2 \cdot 2 \cdot 3$ イ オ ン 源}

イオン源は日立 $\mathrm{T}-2$ 型イオン源のイオン化函に, 電子流の流机に直角の方向に，イオン化光入射のため のカナールを設けた。カナールの断面は, 入射位置で $2 \mathrm{~mm} \times 6 \mathrm{~mm}$ ，出射位置で $4 \mathrm{~mm} \times 8 \mathrm{~mm}$ ，の先開きの 長方形である。

$$
2 \cdot 2 \cdot 4 \text { コレクター部 }
$$

コレクター部はFig. 2 (a) (b) に示したように二 重コレクター方式である。本研究には使用しなかった

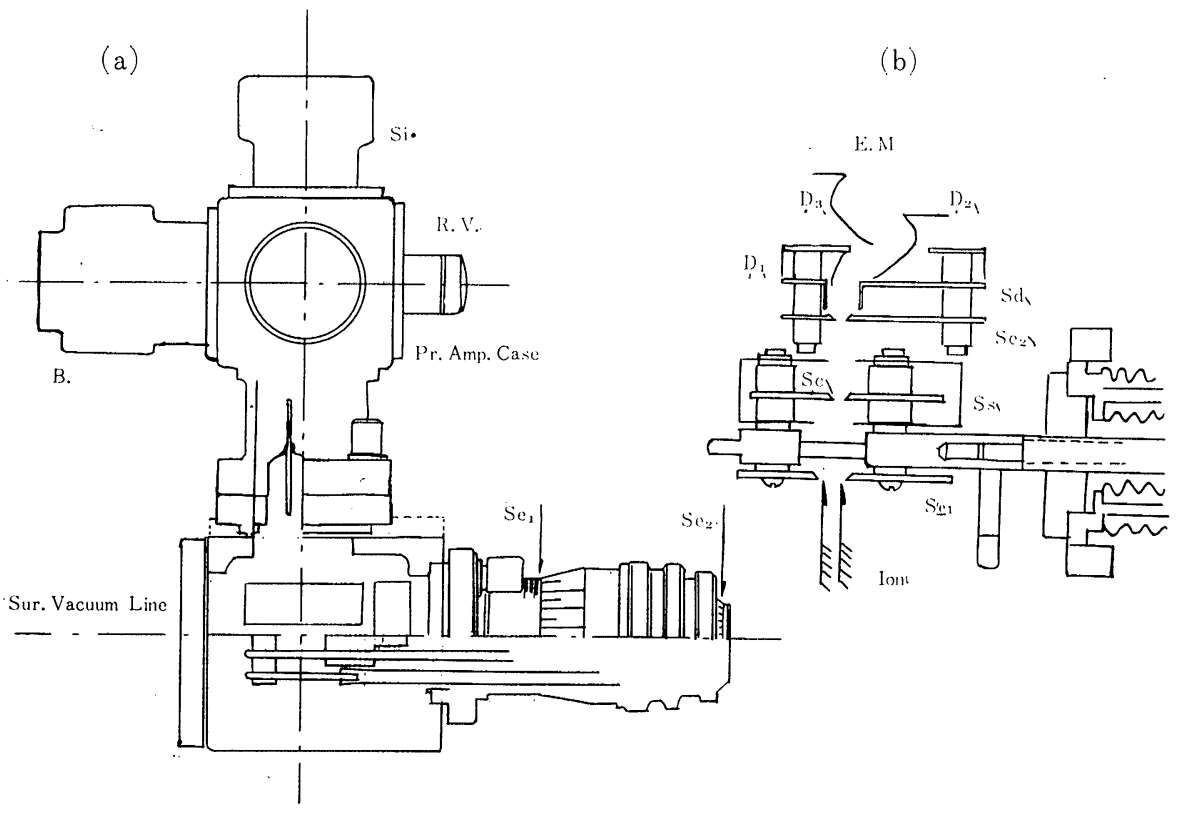

Fig. 2. Schematic diagram of the collector system, (a) cross section of the collector block, (b) slit system,

$\mathrm{S}_{i}$ : Silica-gel box, R.V.: Conversion switch of the high resistance,

B: Dry battery box, $\mathrm{S}_{c 1}$ and $\mathrm{S}_{c 2}$ : Finger screws for adjustment of slit position,

E.M.: Electron multiplier, $\mathrm{D}_{1}$ : Conversion dynode of E.M.,

$\mathrm{D}_{2}$ and $\mathrm{D}_{3}$ : Dynodes of E.M., $\mathrm{S}_{\mathrm{D}}$ : Ion defrection plates,

$\mathrm{S}_{\mathrm{E} 2}$ and $\mathrm{S}_{\mathrm{E} 1}$ : Earth slits, $\mathrm{S}_{s}$ : Supressor box, $\mathrm{S}_{c}$ : Collector plate.

が, 微小イオン電流検出のための二次電子增倍管(6)を 装着するために，98mm㑇のコレクターブロックはそ の中心を分析管の中心から $10 \mathrm{~mm}$ 檤曲部の内侧の方 向に偏心させて熔接されている。Fig. 2(a) はコレ クター部の全体を分析管側から見た略図である。上部 は初段增巾器ケース, Si は初段増巾器内部の乾燥用 のシリカゲル容器, B はサプレッサー電压印加用乾電 池ケース, R.V.はケースに内藏されている抵抗の異 なる2本の高抵抗の切換えスイッチ， $\mathrm{Sc}_{1}$ および $\mathrm{Sc}_{2}$
はスリットシステム全体およびスリッと巾の開閉を行 なうためのスクリューで，移動目盛によりスリットの 位置および币を外部から読めるようになっている。

Fig. 2 (b) はコレクター部分のスリットシステム の略図で， $\mathrm{S}_{\mathrm{E} 1}$ は接地スリット， $\mathrm{S}_{\mathrm{c}}$ は石英製スペー サーにより電気的に絶緑された 2 枚の電極よりなり, 一方を接地し他方をコレクタープレートとして使用し， イオン電流の直接検出に使朋する。ただし，てのコレ クタープレートの巾は外部から变えら机ず，スリット 
巾固定のコレクタースリットとしての働きをするに過 ぎない。 $\mathrm{S}_{\mathrm{s}}$ はコレクタープレートからの二次電子の 抑止電压印加箱である。イオンの焦点位置は $\mathrm{S}_{\mathrm{c}}$ であ るが，測定されたイオン束のゆは $0.3 \mathrm{~mm}$ 程度であり， コレクタープレートがイオンに嚗されている部分の巾 を $0.5 \mathrm{~mm}$ にとれば，分解能 300 を安定して得ること ができる。とのコレクターシステムは $\mathrm{S}_{\mathrm{C} 1}$ により Fig. 2 (a) の図面上左仁にそれぞれ $4 \mathrm{~mm}$ 移㽖叮能で，二 次電子增倍管のスリット位置とコレクタースリット $\mathrm{S}_{\mathrm{C}}$ の位置をイオン入射に刘して一致させることがで きるようになっている。また $\mathrm{S}_{\mathrm{c}}$ スリットの川は0〜 $2 \mathrm{~mm}$ 过闭開きに问変である。なお，Fig. 2 (b) の E.M. 部分は二次電子増倍管の先端部で, $\mathrm{S}_{\mathrm{E} 2}$ はアー ススリット， $\mathrm{S}_{\mathrm{D}}$ はイオン偏向用プレート， $\mathrm{D}_{1}$ は変 换ダイノード， $\mathrm{D}_{2}, \mathrm{D}_{3}$ 等はダイノードである。本研 劣では専ら $\mathrm{S}_{\mathrm{c}}$ プレートによりイオン電流を検出した。

\section{$2 \cdot 3$ 試 料 導入系}

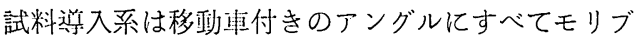
デンガラスを使朋して組込み自製したものを使用した。 ガス溜は $5 l$ の舞星のガラス製フラスコを 2 個取付け, ガス溜の日时は感度の異なる2個のガラス製 McLeod Gauge により测定した。ガスリークはガラス製オリ フィス型で，単位压打にける流量 $0.166 \mathrm{cc} / \mathrm{min}$ お よび $2.29 \mathrm{cc} / \mathrm{min}$ の 2 種類を使用した。また, 将作㳩 分析の感度測定のため，ガラス製活栓 2 個によって产 昷 $1,005 \mathrm{cc}$ のガスピペットをガスリークと並列に取付 けて使用した。

\section{$2 \cdot 4$ イオン電流の増巾と検出}

イオン電流の増ゆには初段に5886 管を使用した通 常の直流增巾器を使用した。なお，高抵抗は $5 \times 10^{9}$ および $5 \times 10^{10} \Omega$ をそれぞれ初段增门器ケースに内蔵 し使用した。嫏録犃は三栄测器製 4 素子オッシログラ フを使用した。奏用感度は初期の㗢作䡃分析の埸合は $4.28 \times 10^{-14} \mathrm{~A} / \mathrm{div} .$, 爾後の静作䡃分析の埸合は $1.12 \times 10^{-14} \mathrm{~A} / \mathrm{div}$. である。

\section{$2 \cdot 5$ 電離 真空計}

電離空副 TEN I.G.-20 Bayard-Alpart 型を Fig. 1 の I.G. の位置, すなわちイオン源と分析管および Hintenberger 式主バルブの絬合点に, $15 \mathrm{~mm} \phi, 100$ $\mathrm{mm}$ 長さのモリブデンガラス㝦で接続して使用した。 各電極の電压配分は，㳺陰極に刘し，電子コレクタ一 格子は $160 \mathrm{~V}$ ，イオンコレクター針は $-45 \mathrm{~V}$ にした。 イオン電流の測定はすべて電子電流 $2 \mathrm{~mA}$ で, Takeda Riken TR-5 型 $\mu$ - $\mu$ アンメーターを用いて增巾検出 した。また，各霆極の脱ガスは、コレクターと格子電 極をそれぞ狆淎陰極に刘して $600 \mathrm{~V}$ にし，電子電流50 $\mathrm{mA}$ で衙軻㸝する热すことにより行なった。

\section{$2 \cdot 6$ 分析管等の脱ガス用焼出し電源}

分析管の焼出しは 2KVA のワンターントランスの 二次電流を分析管に直接通電する方式を用い，主磁石 をはずし，アスペスト板で分所管を熱的に掩洲し， $400^{\circ} \mathrm{C}$ 迄加熱した。そのために必裂な電力はワンター ントランスの一次侧で $160 \mathrm{~V}, 4 \mathrm{~A}$ である。イオン源, コレクターおよび主バルブの各ブロックと排気管の焼 出しには，300W のテープヒーター2本と $300 \mathrm{~W} ア$ イロンヒーター9個を使用した。このための電気谷量 は $3 \mathrm{KVA}$ で，これらの全体を約 $130^{\circ} \mathrm{C}$ に保つため の所裂電力は約 $1.5 \mathrm{KW}$ である。

イオン源の燒出しは, イオン源の電子トラップに絶 緣して取付けられた加熱用フィラメントにより $300^{\circ} \mathrm{C}$ に保った，その所䀳電力は約 $30 \mathrm{~W}$ である。

\section{3. 排気, 真空特性およびバッグラウンド}

\section{$3 \cdot 1$ 排気スケジュールと到達真空度}

本装置（質量分析部）は製作工場において内壁を電 解洗浄し，佬出しを行なわずに排気し，漏洩試験を行 なった後解体発送された。当研栄等における排気は次 のようなスケジュールで行なった。(1) 汕回転ポンプ と油拡散ポンプの間のトラップをドライアイスーエタ ノール寒剂に浸した後油回転ポンプを作動し，装置全 体を排気する。約20分間の排気によりテスラーコイル によるガラス部分からの放電色および螢光が消える。

(2) 乙の時点において, 油拡散ポンプ上部のドライア イストラップおよびそれより高监空侧の液休窒素トラ ップをそれぞれ冷却した後油拡散ポンプを作動する。 最初の排気では約 4 時間で $8 \times 10^{-6} \mathrm{mmHg}$ に達した。 （3）ここで主バルブを閂じ，トラップの焼出しを行な う。液棣窒絜トラップは寒剂を取除いてガスバーナー により断続的に加桑し，ドライアイストラップは寒剂 を取除いて师简形ヒーター $(1 \mathrm{Kw})$ を入れ，80V3.5A で約 1 時間加熱する。その後油回転ポンプと油拡散ポ ンプの間の電磁バルブを閉じ，その間のドライアイス トラップを充贸にガスバーナーで焼出しする。以上の トラップ焼㥙し操作は，定常䦽転中は 1 週間に 1 回行 なっている。(4) トラップ烧出し終了後(1)(2)の操作に もどし，监空度が $10^{-6} \mathrm{mmHg}$ に達した後に分析管を $400^{\circ} \mathrm{C}$ ，ブロック部を $130^{\circ} \mathrm{C}$ にそれぞれ加㷊する。 北熱により罣度は低下して 2 洔間後に約 $2 \times 10^{-5} \mathrm{~mm}$ $\mathrm{Hg}$ となり，以後除除に上扑する。(5) さらに这空度 が $10^{-7} \mathrm{mmHg}$ に達した後イオン源ヒーターによりイ オン源を除除に加熱し，本体焼汒し時には常に $250^{\circ} \mathrm{C}$ を保つようにする。イオン源の電子昰繋用フィラメン トの作郋により，イオン源のイオン化守はほほ $80^{\circ} \mathrm{C}$ に達する。以上の缆き忙しは主として伩間に行ない，

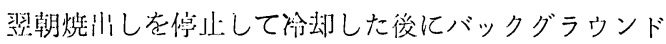


Table 1. End vacuum and background peaks under primary dynamic operation.

\begin{tabular}{|c|c|c|c|c|c|c|c|}
\hline \multirow{2}{*}{$\begin{array}{c}\text { Duration of } \\
\text { bake out } \\
\text { (hours) }\end{array}$} & \multirow{2}{*}{$\begin{array}{c}\text { End vacuum } \\
(\mathrm{mm} \mathrm{Hg})\end{array}$} & \multicolumn{6}{|c|}{ Background peaks (div.*). } \\
\hline & & $\mathrm{M} / \mathrm{e} 12$ & 14 & 16 & 18 & 28 & 44 \\
\hline 22 & $1.1 \times 10^{-6}$ & 0.4 & 0.2 & 2.7 & 70.2 & 3.2 & 3.5 \\
\hline 43 & $2.5 \times 10^{-7}$ & - & 0.2 & 1.4 & 13.8 & 2.8 & 2.0 \\
\hline 59 & $3.8 \times 10^{-8}$ & - & - & 0.4 & 3.7 & 0.7 & 1.2 \\
\hline 77 & $2.0 \times 10^{-8}$ & - & - & 0.1 & 1.9 & - & 0.7 \\
\hline 182 & $1.0 \times 10^{-8}$ & - & - & - & - & - & - \\
\hline
\end{tabular}

* 1 div. corresponds to $4.28 \times 10^{-14} \mathrm{~A}$.

を測定することを繰返した。この焼出し時間の経過に よる具空度の上杽拈よびバックグラウンドの成少の測 起例を Table 1. に示す。Table 1. の結果は本体お よびイオン源の冷却状態を必ずしも一致させていない ので，烧出し特間に対する完全な対芯は示していない
が，初期の排気傾向を示したせのである。Table 1 . からわかるように，焼出しによる M/e18 の減少は顕 藷で，182時間では $1 \times 10^{-14} \mathrm{~A}$ 以上のバックグラウン ドイオンは動作動においては認められないようになる。 このようにして通算 250 洔間の㘹出し排気により到達

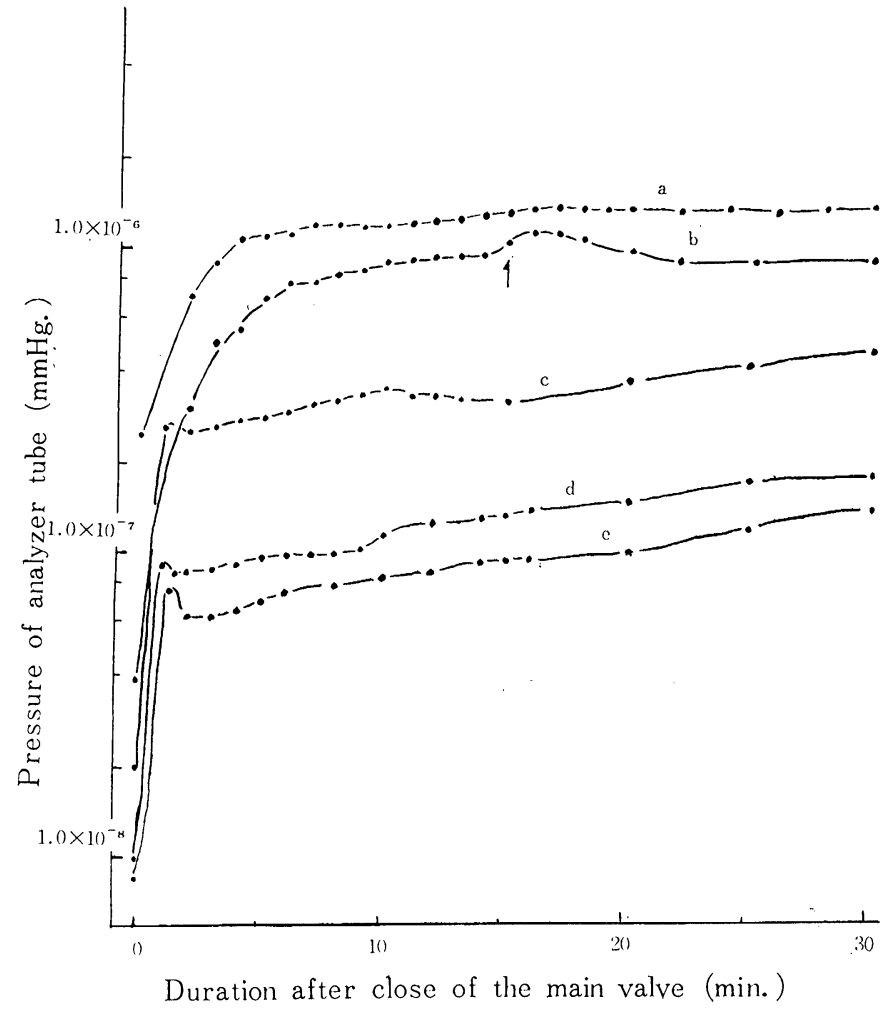

Fig. 3. Time variation of vaccuum under static operation at various bake out duration.

$\begin{array}{lccccc}\text { Curve } & \text { a } & \text { b } & \text { c } & \text { d } & \text { e } \\ \text { Bake out duration (hr.) } & 43 & 59 & 77 & 182 & 198\end{array}$

The arrow in curve $b$ shows that the ion source heater was off, other curves are the results obtained without use use of the ion source heater. 
尖空度は $2 \times 10^{-9} \mathrm{mmHg}$ に達し，烧けし中の高空度 は約 $7 \times 10^{-7} \mathrm{mmHg}$ であった。

\section{3・2 静作動時の真空度とその焼出しによる変化}

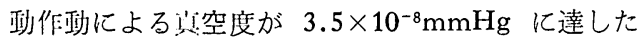
後主バルブを阙じ，電離其空計で測定した静作動によ 万分析管内部の压力増伈の測定例を各焼出し通算時間 每に Fig. 3 亿示す。

曲線 a,b,c,d,e はそれぞれ焼洁し通算特間 43，59， 77，182 および 198 時間に対応し，曲總 b の矢印はこ の点运イオン源ヒーターを入机たままにし，ての点で ヒーターを切ったととを示す。Fig. 3 の各曲線によ ればいずれも5分内外でほぼ平衡压に達している。ま た，曲線 c, d,e では急激に空度が低下した後一封 具空が上ってから再びゅっくりと低下する状態を示し ているが，てれは主バルブの銅球と銅球受けが虽い力 を受けて接触した際に吸叐ガスが脱離し，電離顛空計 の排気作用によりその一部が排気されたものと想像さ れる。したがって, 各曲線が半衡压を示すのは, 器壁

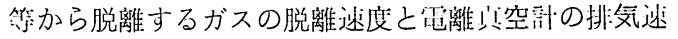
度が等しくなった状態と考えられる。しかし，各曲線 ともを焼出し時間の增加にともなって，怔作﨡時の到 達产空度の上筷と共に半衡压が減少しているととが明 かである。

\section{3・3 静作動におけるバックグラウンド}

$3 \cdot 3 \cdot 1$ 電離宾空㖕作怔時のバックグラウンド

Fig. 3 に対応して，分析倍内のバックグラウンドを 分析した一例（焼汕し通算227時間後）を Fig. 4 に示 す。解離イオンの解析結果によると, Fig. 4 亿示した $\mathrm{M} / \mathrm{e} 2$ は水素, $\mathrm{M} / \mathrm{e} 16$ はメタン, $\mathrm{M} / \mathrm{e} 28$ の80\%以上 が $\mathrm{CO}$ である。なお，Fig, 4 の矢印 $\mathrm{A}$ は電離突空計 を2.5に述べた焼出し状態にした時間，Bは電離】这空 訣を測定状態にした時間，Dは主バルブを閉じた時間， E は过バルブを開けて排気状態にした時間をそれでれ 示す。また，四解の点は石の縦軸に示した刘数スケー ルによる分析得内の空度である。

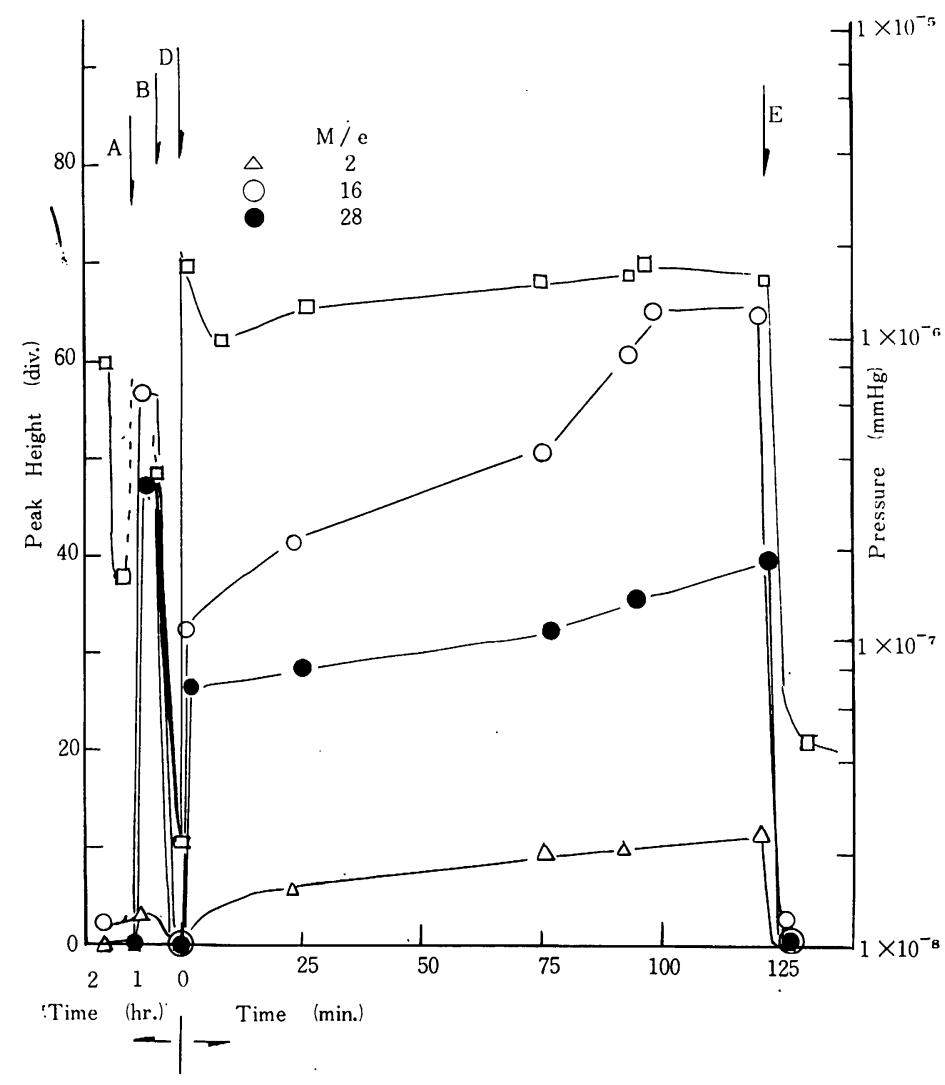

Fig. 4. Variation of background peak heights $(\triangle, \bigcirc, \bigcirc)$ and pressure $(\square)$ with time under static operation after total 227 hours' baking. Arrows indicate following procedures: the ionization gauge was bombarded $\mathrm{A}$; at the ionization gauge operated at $\mathrm{B}$; the main valve was closed at $\mathrm{D}$; the main valve was opened at $\mathrm{E}$. 
Fig. 4 に示した笑験では主バルブを阙じる 1 時間半 前に真空度は $1.7 \times 10^{-7} \mathrm{mmHg}$ となり, 残留ガスと しては少量のメタンが検出される。とてで電離蒖空計 のグリッドに $600 \mathrm{~V}$ 印荷し, 電子電流 $50 \mathrm{nA}$ で㜔出 し状態にすると, メタンおよび CO が著しく增加し， 水素は極くわづか検出される。約 30 分の焼出し後電離 臭空計を測定状態にもどすと，急速にすべての残留気 休は減少し，同時に真空度はほぼ $2 \times 10^{-8} \mathrm{mmHg}$ 迄 上是する。Fig. 3 によればての真空度では冷却が不光 分であるととがわかるが，乙の点で主バルブを閉じる と, Fig. 3 の曲線 e のように具空度は著しく低下した 後いったんやや上鼠しし，その後は除除に低下してほ
ぼ半衡正汇達する。しかし，各イオン電流は一眭的な 極大壳示さず，メタンおよびCO は急激に上帠したの ち除除に増加する。また，予想された $\mathrm{M} / \mathrm{e}=18, \mathrm{M} / \mathrm{e}$ $=44$ 等のピークは検出さない。電離真空計による戍 力值とイオンのピーク高が必ずしも対応しない:のは， 主バルブに対する電離真空計の位置と開放度の相遠に よるものと思われる。

$3 \cdot 3 \cdot 2$ 電離真空計を作動しない埸合における静 作動状態のバックグラウンド

以上の結果加ら電離点空計が相等大きな排気作用を 持つととが明かであり，静作動分析にあたって電離真 空副を使用するのは適当でないととが明かとなった。

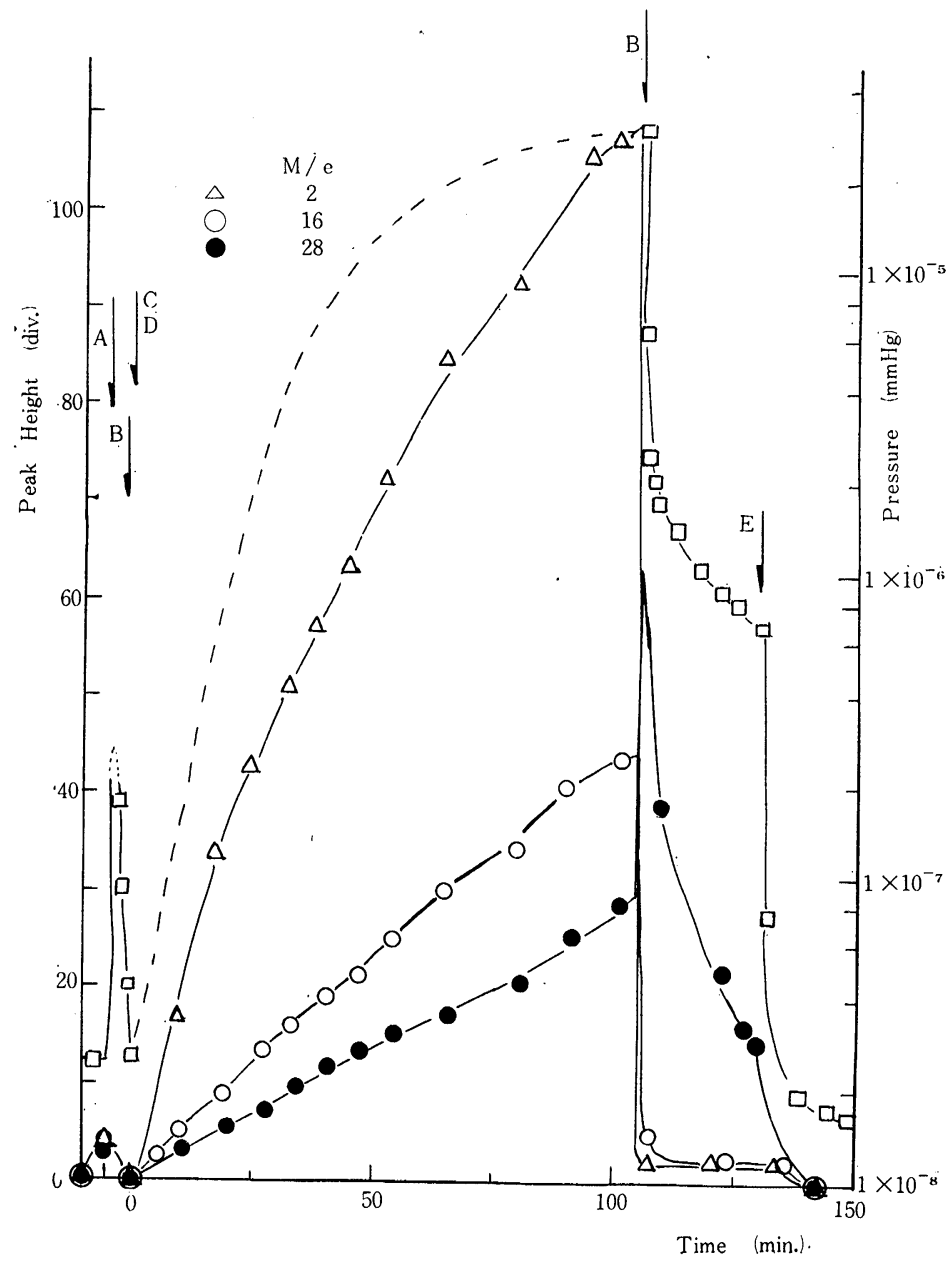

Fig. 5. Time variation of background peak heights $(\triangle, \bigcirc, \bigcirc)$ and piessure $(\square)$ under static operation after total 241 hours' baking. The ionization gauge was worked on again at the time shown by the arrow $B$ in the right side. Other arrows indicate following procedures: the ionization gauge was bombarded at $\mathrm{A}$; the ionization gauge operated at $\mathrm{B}$ in the left side; the ionization gauge was off at $\mathrm{C}$; the main valve was closed at $\mathrm{D}$; the main valve was opened at $\mathrm{E}$. 
したがって，䉓離具空计を作政しない晹今の静作動将 のバックグラウンドが問題となる。この埸命の咨駼例 として焼泏し通算 241 時間の場合を Fig. 5 亿，また 烧出し通算 256 時間の場合を Fig. 6 に，それぞれ示 す。こ机らの図における知卯Cは電離点空部の電源を 切った封間を示し，その他の矢印は Fig. 4 の埸命と 同様である。

Fig. 5, 6 と: Fig. 4 との比較加ら扐るように, 主バルブ|鎖後は水䋕の增加が著しく、メタンおよび $\mathrm{CO}$ は烍出し㭙間の增玑によって器壁加らの脱離が娍 少している。また，柴空度は Fig. 4 の平衡压より低 下し，そのほとんどが水素であるととが明らかである。 なお，Fig. 5 と Fig. 6 の比較加わかるように，メ タンとCO は明らかに焼湍し時間の增加により減少し
ているにもかかわらず水烮はほとんど成少していない。 このことから水素を減少させるととは欲易でないとと がわかる。Fig. 5, 6 の 100 分以後の矢印 Bにおいて

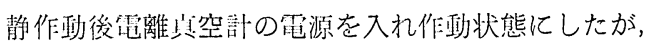
いずれの場合む点火直後の压力は大きく，その後空 度の急速な上郘が認められる。てのような空空の変化 に対応して水素およびメタンの昷もやはり急速汇減少 しているが，CO は一時的に增大した後水玨およびメ タンに比べてゆっくりと娍少するととを示している。 このCO の大部分は雪離突空部のタングステングリッ ドがイオン化用電子の衙整により加染されて放出した あのと考元られ, 分析結果から点空度が上㤠した後の 平衡压はこの状態（焼出しの程度）ではそのほとんど が電離战空湖からのCO であるととが加かる。

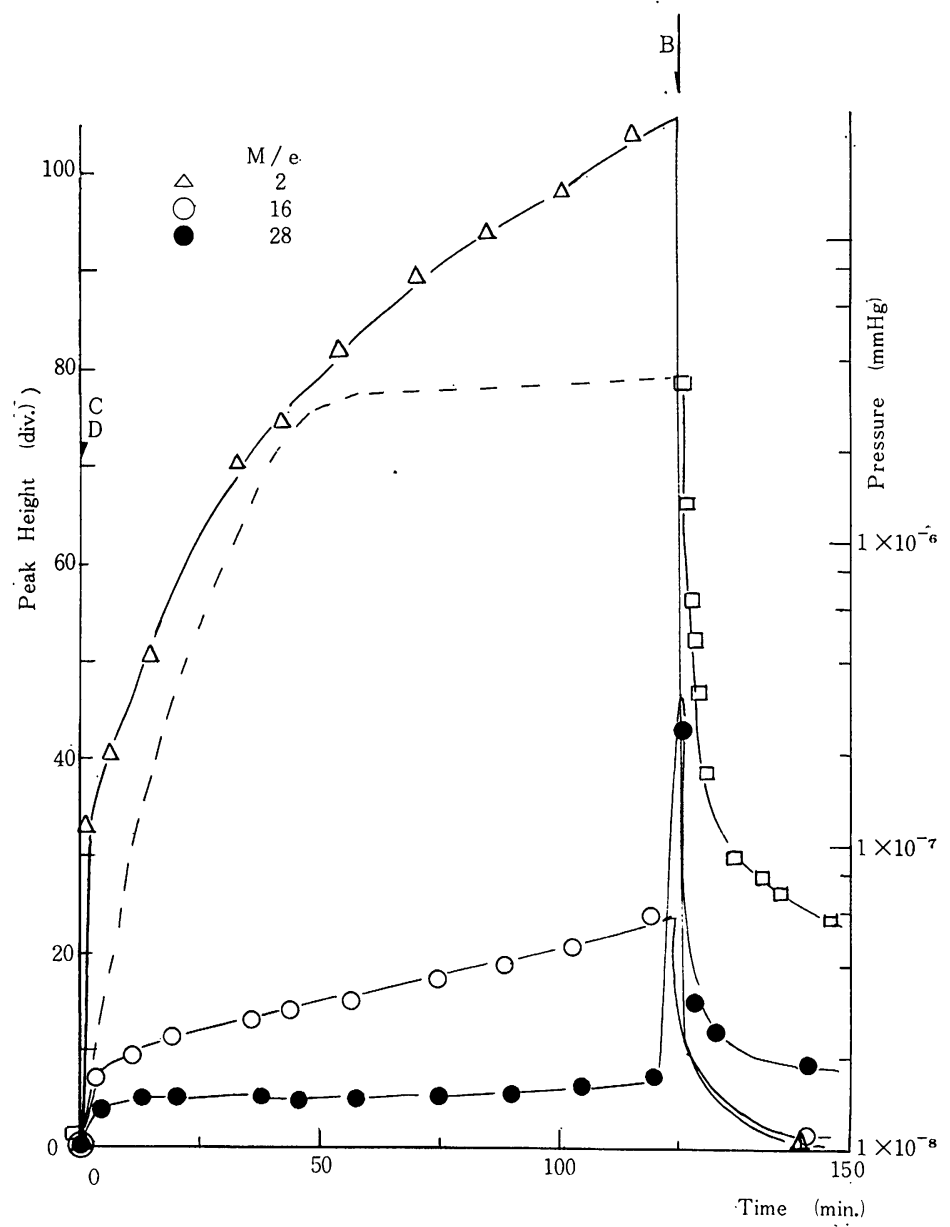

Fig. 6. Time variation of background peak heights $(\triangle, \bigcirc, \odot)$ and pressure $(\square)$ under static operation after total 256 hours' baking. The ionization gauge was worked on again at the time shown by the arrow $B$ in the right side. Other arrows indicate following procedures: the ionization gauge was off at $\mathrm{C}$; the main valve was closed at $\mathrm{D}$. 


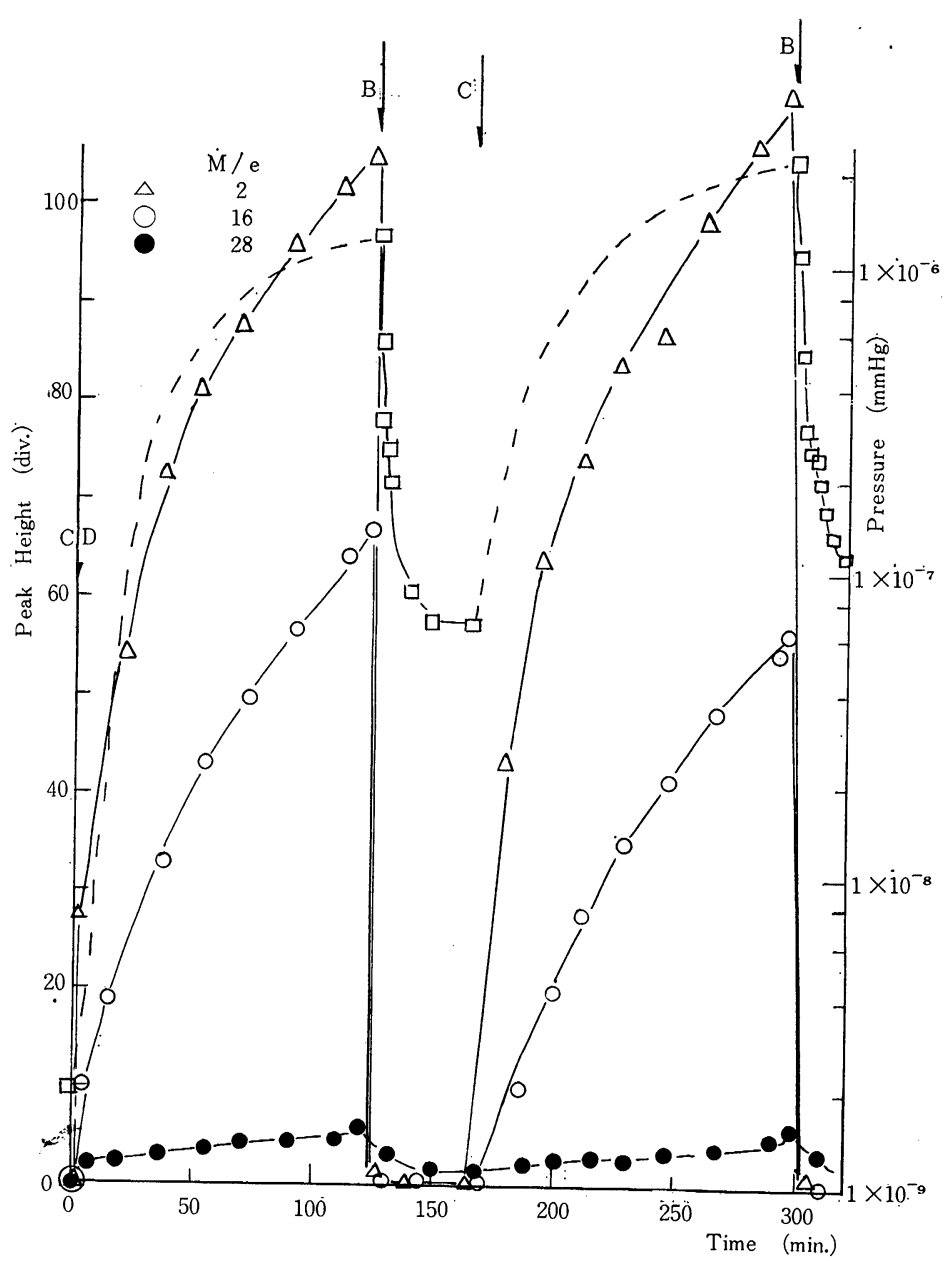

Fig. 7. Variation of background peak heights $(\triangle, \bigcirc, \bigcirc)$ and pressure $(\square)$ with time under repeated static operations after total 363 hours' baking.

Arrows indicate following procedures: the ionization gauge was worked on at $\mathrm{B}$; the ionization gauge was off at $\mathrm{C}$; the main valve was closed at D.

\section{$3 \cdot 3 \cdot 3$ 静作動中に扔ける電離真空計の点滅}

静作䙲中に電離点空詶を点火すると，その排気作用 により具空度は上晶し残留ガスが成少することが明か となったが, 電離点空計の排気速度と器壁からの気作 の脱離速度がほぼ平衡に達した後に再び電離点空計の 電源を切った場合の实鍳例（焼出し通算時間 363 時 間）を Fig. 7 に示す。Figs. 5，6 の結果に比べて Fig. 7 では CO は減少しているが，水素はほとんど 変化がなく、メタンはかえって増加している。てれは Fig. 7 に示された奜験では分析管およびイオン源の冷 却が充分でなく，温度の影響によるものと思われる。 このことから，水素の脱離は温度にあまり影響されず， 洄熱，排気によっても静作動時における残留水素の減
少はかなり困難であるととがわかる。またメタンが 比較的早く脱離することも Fig. 7 における増加から 理解される。なお，Fig.7のくりかえされた静作動に よると水䒺とCO はほとんど同一の脱ガス量を示して いるが, メタンは後の静作動に氺いてかえって減少し ている。

このことは電離真空計に吸着したメタンが脱離して いるのではないてとを湆味していると若えられる。

\section{4. 種種の気体に対する電離真空計の排気作用}

Figs. 4〜7 に示した静作動時のバックグラウンドに 関する知見から，水素は電離基空計により急速に排気 されるに対し，CO は水素に比べて排気され難く，電 

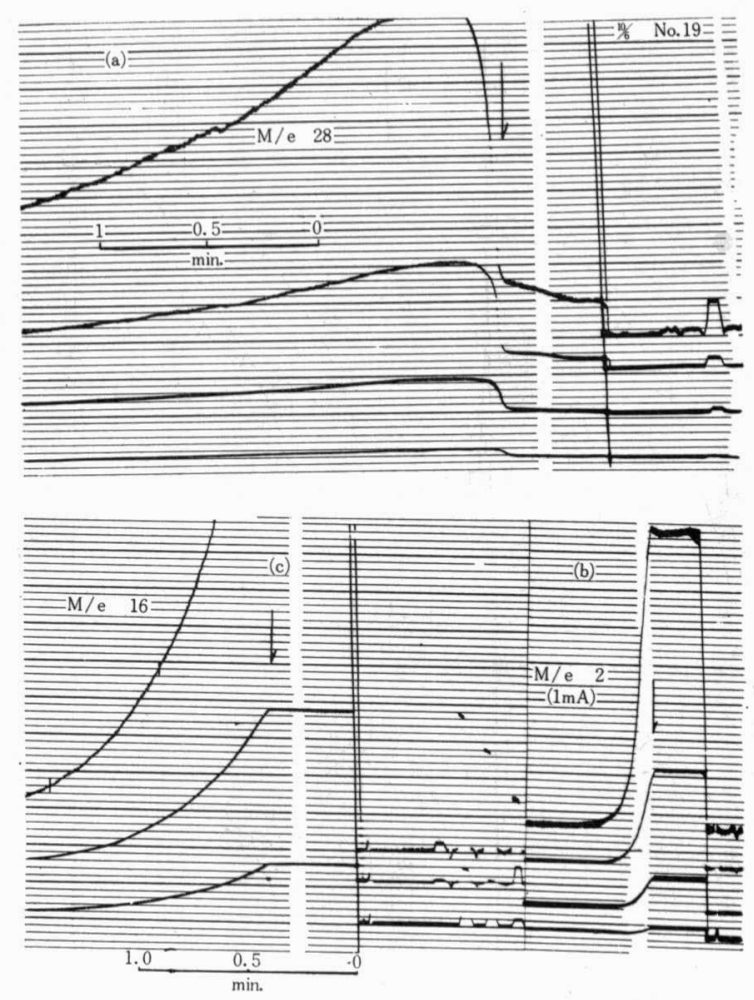

Fig. 8. Oscillograms showing ion current decrease of background gases by pumping action of the ionization gauge. Electron emission currents of the ionization gauge were $2 \mathrm{~mA}$ for (a) and (c), and $1 \mathrm{~mA}$ for (b). The time at which the filament of the ionization guage was electrically heated is shown by each arrow.

(a) $\mathrm{M} / \mathrm{e}=28$, (b) $\mathrm{M} / \mathrm{e}=2$, (c) $\mathrm{M} /=\mathrm{e} 16$.

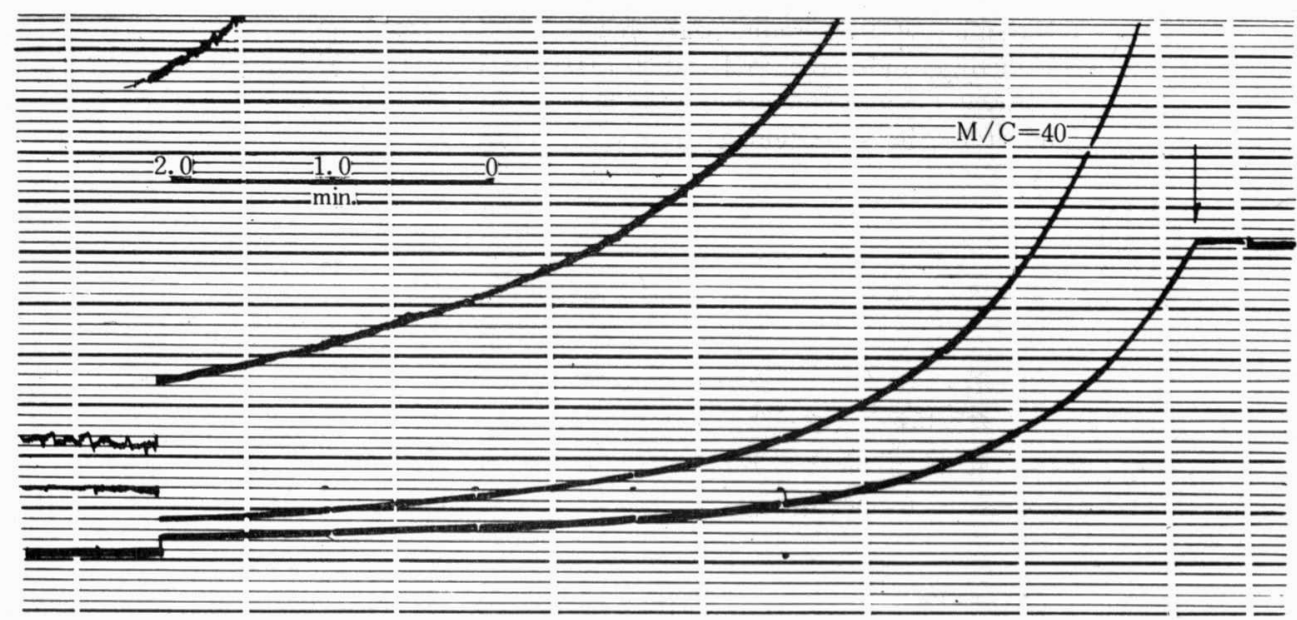

Fig. 9. Oscillogram showing ion current decrease of ${ }^{40} \mathrm{Ar}$ by pumping action of the ionization gauge. Electron emission currents were $2 \mathrm{~mA}$, and the time at which the filament of the ionization gauge was electrcally heated is shown by the arrow. 
醀紧空蔀の排気作用は気体の種類によって渚しく異な ることがわかった。この排気作用を種種の気体につい て測定するために，静作動により一定压力の気体を分 析管内に満したのち, 啠量分析計の主磁場の強さを特 定の M/e のイオンビームがコレクターに受けられる ように調整し，イオン電流が一定になった後あらかじ め所定の衝整電子流が流れるように設定した電離具空 涪のスイッチを入れ，記録紙上にイオン電流の変化を 記録する実験を行なった。測定結果の数例を Figs. 8， 9 亿示す。

Fig. 8 (a) はバックグラウンドの M/e 28 のイオ ンの電離真空計点火によろイオン電流の減少を示した あのであり，概述のようにこの約 $80 \%$ 以が $\mathrm{CO}$ であ る。減衰曲線の右側に $\mathrm{M} / \mathrm{e} 28$ 付近の質量スペクト ルが示されており，フィシメント点火によりイオン電 流がいったん念激に増加した後除除に減少している。 注意深く見ると著しくイオン電流の增加する約10秒前 にイオン電流のわずかな増加が認められる。これは Fig. 8 (b)，(c) には見られないむのであるが，電離 買空計の電極に吸着されていたCO がフィラメント点 火の10秒ほど前にグリッドに印师された電圧によりコ ロナ放電が起ったためにわずかに脱離されたすのと落
えられる。 $\mathrm{CO}$ の場合は点火後のイオン電流の一時的 増加は $10^{-9} \mathrm{mmHg}$ 程度の真空度では避けられないが, 点火後約 1 分を経過すると減衰曲線は他の場合と同様 な指数函数的な曲總になる。 Fig. 8（b）はバックグ ラウンドの $\mathrm{M} / \mathrm{e} 2$ で電子電流は $1 \mathrm{~mA}$ である。また, 曲線（c）はバックグラウンドの M/e 16 (メタン) の測定例である。Fig. 9 に桸ガスの一例としてアルゴ ンの M/e 40 の曲線を示した。なお, 記録紙の送り 速度の精度は $2 \%$ 以下であり, 速度測定の際の時間は オシログラフの構軸の距離をとった。

各気体についてのイオン強度の特間的変化を Fig. 10 に示す。 $\mathrm{H}_{2}$ およぶ $\mathrm{CO}_{2}$ は減少速度が他に比べて 著しく大きいので図中には省略した。Fig. 10 の縦軸 のイオン量は任意の単位を取ったが，各直線の勾配は 垁験の測定範囲すなわち分析管内の圧力が $10^{-5} \mathrm{~mm}$ $\mathrm{Hg}$ 以下では良好な再現性を示した。また，各直線の 勾配は $500 \mu \mathrm{A} \sim 10 \mathrm{~mA}$ の範囲の電子電流では電子電 流に比例する。以上の結果から，電離䔬空計による排 気における圧力変化を実験式 $-d P_{i} / d t=k_{v} P_{i}$ で表わ すことができる。ただし， $P_{i}$ は各気体の分圧， $k_{v}$ は 排気速度定数である。 $k_{v}$ はもちろん気体によって異 なり，一定気体では正力に無関係で排気される容量に

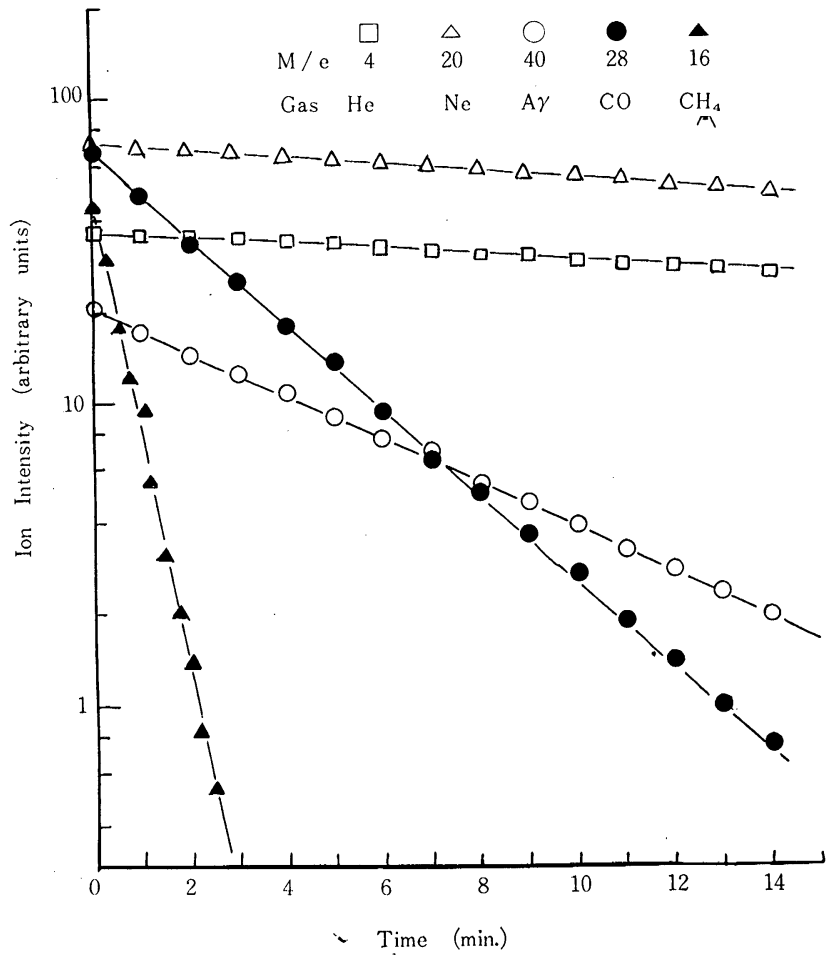

Fig. 10. Semilog plots of ion intensity vs time of evacuation by the Bayard-Alpert type ionization gauge. Electron emission currents of the ionization gauge were $2 \mathrm{~mA}$. 
父比例しかう笔子雪流に比例する。桓種の気体につい て測定された雱子電流 $2 \mathrm{~mA}$ の場合の $k_{v}$ を Table 2 に示す。ただし， Table 2 の值はこの実駼で使用した 分析管部分の容䖽（約 $2 l$ ) についての数值である。

Table 2. Evacuation rate constants $\left(k_{v}\right)$ of various gases by the Bayard-Alpert type ionization gauge (emission currents were $2 \mathrm{~mA}$ ).

\begin{tabular}{c|c|c}
\hline \hline Gases & $k_{v}$ (analyzer volume/min.) & Relative rate \\
\cline { 2 - 3 } $\mathrm{He}$ & 0.0199 & 0.123 \\
$\mathrm{Ne}$ & 0.0303 & 0.187 \\
$\mathrm{Ar}$ & 0.162 & 1.00 \\
$\mathrm{H}_{2}$ & $>22.1$ & $>136$ \\
$\mathrm{CH}_{4}$ & 1.92 & 11.8 \\
$\mathrm{CO}$ & 0.317 & 1.96 \\
$\mathrm{CO}_{2}$ & 14.3 & 88.2 \\
\hline
\end{tabular}

Table 2 には比較のためにアルゴンを基準にした排 気速度定数 $k_{v}$ の相対值も示してあるが，稀ガスにつ いてはほぼイオン化確率の比となっており，電離其空 㳯による排気は電離された稀ガスイオンがコレクター または管壁に電気的に加速さ机て吸着するととによる あののようである。静作溗分析において一度電離突空 部に吸着された稀ガスが容呱に脱離しないととは，単 なる吸着とは考えられない。稀ガスに比べて他の気体 の排気速度はかなり大であり，かつ相刘值は電離確率 と関係がない。たとえば， $\mathrm{CO}$ はアルゴンの1.96倍で あるが $\mathrm{CO}_{2}$ は88.2傜，電離確率の小さいはずの $\mathrm{H}_{2}$ は 136 倍以上である。したがって，て机らの埸合は接
侽解離等を宩えなけ机ばならない。ととに水絭はいわ ゆるクリーンアップによると考えられる。問題は電子 電流に排気速度が比例することであるが，電子電流の 增加ととあにフィラメント表面の温度む上颅している はずであり，また電子電流の问変籰用が狭いととを考 虑に入れると，必ずしも矛盾した絬果ではないと考え ら机るが，稀ガス以外の気体に対する電離!空計の排 気作用についてはさらに榆剷を翼する。

\section{5. 静作動分析における感度}

アルゴン，ネオンおよびヘリウムの各稀ガスイオン について静作動分析における忽度を測定した。まず主 バルブを閉じ, 電離㷫空尌の電源を切り, イオン源を 分析動作状態にし，特定の M/e のイオンがコレクタ 一で検出されるように主磁場を調整し，記録紙を送り 状態にして，次の 2 種類の方法によって測定した。

（カ法 I） 2・3 に述べたガラス製グリースコックで 作ら机た空稳 $1.005 \mathrm{cc}$ のガスペットに一定に:の稀ガス を取り，ガラス製グリースコックを開いて稀ガスを分 析管内に送り込み, イオン電流の時間的変化を記録し

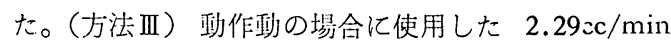
の流量のガスリーク部分へガラス製グリースコックを 開開して一定量の稀ガスを封じ込少，ガスリークから 分析管入巔入された稀ガスのイオン電流の時間的変化 を記録した。このガスリーク部分の行䅡は 7.3ccであ 万。

なおゔリースコックに使用したグリースはアピエゾ ンNであるが，グリースから出ると思吅机る炭化水装

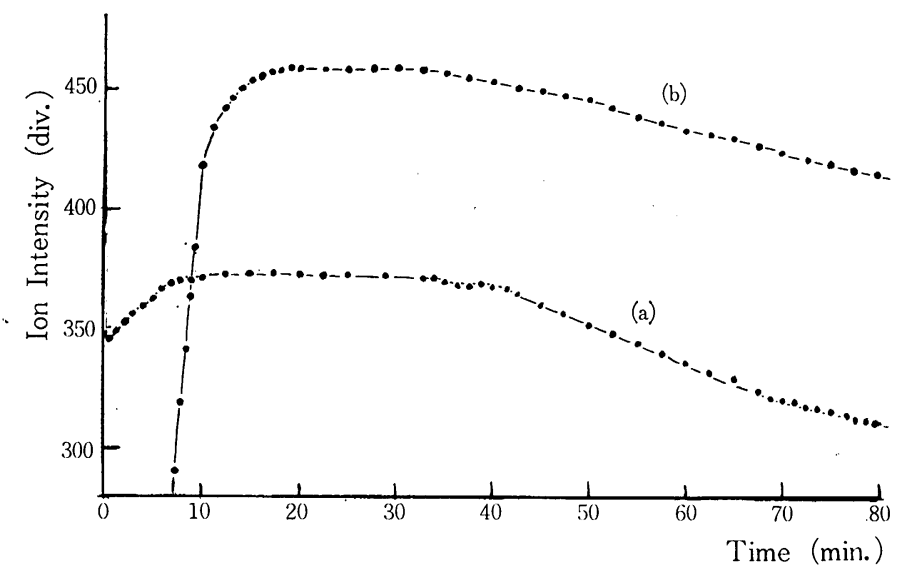

Fig. 11. Change of ${ }^{40} \mathrm{Ar}^{+}$ion intensity under static operation.

Curve (a): argon was introduced from a small gas pipette into the ion source and analyser tube, and the pressure in the gas pipette was $4.93 \times 10 \mathrm{~mm}^{-3} \mathrm{Hg}$.

Curve (b): argon was introduced through a gas leak into the ion source and analyzer tube, and the pressure in the gas leak region was $1.01 \times 10^{-3}$ $\mathrm{mmHg}$. 
等のバックグラウンドは, 静作動中無視しうる程度で あった。

以上の 2 つの方法で静作動を行なった場合の ${ }^{40} \mathrm{Ar}$ のイオン䨨流の時間的変化を Fig. 11 に示す。Fig. 11 の曲線（a）は为法Iによるものであり，(b) は方 法Iによるものである。また，各一定寕積に送ったガ ス国は (a) が $4.93 \times 10^{-3} \mathrm{mmHg}$ （b）が $1.01 \times 10^{-3}$ $\mathrm{mmHg}$ である。静作動に打ける分析管内の容積は $2 \pm 0.1 l$ であり，分析管内のアルゴンの分圧は (a) が $2.45 \times 10^{-6} \mathrm{mmHg}$ （b）が $3.69 \times 10^{-6} \mathrm{nmHg}$ である。 (a) の曲繰は，ガス導入が急激でまずイオン源内を相 等高正のアルゴンが通過して分析管内に拡散するため に，イオン源内の圧力は最初減少した後 8 分程度の時 間によりほぼ平衡に達するととを示している。また （b）ではアルゴンがガスリークを通って除除に分析篦 内に拡散されている。いずれの曲線も40分前後からイ オン電流（压力）が㳄第に減少している。ネオンおよ びヘリウムについてもとのようなイオン電流の時間的 減少はみとめられるが，アルゴンに比べると減少の程 度は小さい。とのような琴象は器壁への吸着の他にイ オン源内におけるイオン吸潧も関係していると思われ る。 ${ }^{40} \mathrm{Ar}$ の減少速度は電離其空計の $2 \mathrm{~mA}$ に打ける 排気速度の約 $1 / 20$ となっている。

以上の静作動分析について，アルゴン，ネオン，へ リウムの各稀ガスの存在率の最も大きい同位体の感度 を $\mu \mathrm{ccNTP}$ あたりのイオン電流值で表わした結果を Table 3 に示す。Table 3 では方法Iに比べて方法 II が小さい值を示しているが，乙れは方法IIでは分析 管内に打ける試料の平衡压任達する時間が長いために， 器壁への吸着およびイオン源におけるイオン吸着がよ り多く影響することによると思われる。なお，動作動 分析の感度を此較するために，2.29 cc/min の流量の ガスリークを用いた場合の電流値をガス溜の容量 $1 \ell$ の埸合に換算して $\mu \mathrm{ccNTP}$ 当りのイオン電流值とし て表わした結果を Table 3 のIIIに示す。I と而の感
度比を各稀ガスイオンについて取ると $8 \times 10^{3}$ の一定 值を示し，方法 I では器壁への吸着およびイオン源に おけるイオン吸着の影響はほとんど現われないと考え られる。また，I と而の感度比からわかるように，二 次電子增倍管を使用せず通常の直流增幅器を使用した 静作動分析においては，同一イオン量を得るために動 作動分析で必要な試料量の約 $1 / 8 \times 10^{3}$ でよいととに なる。すなわち, 本研劣に使用した $1.12 \times 10^{-14} \mathrm{~A} / \mathrm{div}$ の程度の普通の直流増巾器および記録計を使用しても， 同位体比が著しく小または大ではない場合については， アルゴンで数 $\mu \mathrm{cc}$ ，ネオンおよびへリウムで数十 あれば静作動分析による同位体比測定が可能であるこ とを示している。

なお， Table 3 の結果によると， $2.99 \mathrm{cc} / \mathrm{min}$ の流 量のガスリークを使用した埸合のイオン源内压力はガ ス溜の压力の $6.2 \times 10^{-5}$ 倍になっているととがわかる。 この結果は一般性はないが，本装置のように排気速度 が比較的大きい装置ではイオン源内の気体の圧力と電 離真空計による分析管内の圧打测定值との関係が求め にくいため，上記の值はイオン源内部の気体の圧力を 知る上で重要である。

\section{6. 結 語}

本装置は真空紫外部光による光イオン化の過程を研 究するととを主目的として製作されたすのであるが， 極微量試料用質量分析計としても使用しうるように設 計されて扣り，静作動と動作動の感度の比較からイオ ン源内の压力についての知見を得るために，静作動分 析の性能およびそれに付随した基空諸現象を本報にお いて検討した。本報に報告した程度の焼出しにより動 作動で $2 \times 10^{-9} \mathrm{mmHg}$ の真空度を得ることができ， 静作動分析を行なっても比較的長時間バックグラウン ドが増加せず，極微量試料用質量分析計として充分に 使用しうるととが明らかとなった。

終りに，同一型式の主バルブの使用を快く許可され

Table 3. Sensitivity (A/ $/$ cc NTP) of noble $\varepsilon$ ases by static operation and the comparative

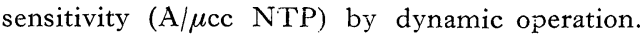

\begin{tabular}{l|c|c|c}
\hline \hline & ${ }^{40} \mathrm{Ar}$ & ${ }^{20} \mathrm{Ne}$ & ${ }^{4} \mathrm{He}$ \\
\hline I, static operatios* & $6.39 \times 10^{-13}$ & $1.26 \times 10^{-13}$ & $6.92 \times 10^{-14}$ \\
II, static operation** & $5.30 \times 10^{-13}$ & $1.21 \times 10^{-13}$ & $6.70 \times 10^{-14}$ \\
III, dynamic operation** & $7.99 \times 10^{-17}$ & $1.58 \times 10^{-17}$ & $8.65 \times 10^{-18}$ \\
Ratio I/III & $8.0 \times 1 \mathrm{C}^{3}$ & $8.0 \times 10^{3}$ & $8.0 \times 1 \mathrm{C}^{3}$ \\
\hline
\end{tabular}

* Gases were introduced from a small gas pippette into the ion source and analyser tube.

** Gases were introduced into the ion source and analyses tube through the gas leak of $2.29 \mathrm{cc}$ /min. flow rate. 
た Max-Planck-Institut für Chemie (Mainz) の Prof. Hintenberger, 本装置の製作に当って御指導御援助を 頂いた大阪大学緒方教授, 大阪大学岡野助教授, 日立 製作所那珂工場牧野工場長，日立製作所中央研究所只 野副所長，日立製作所中央研究所および日立製作所那 珂工場の質量分析関係各位に深く感謝します。

\section{文献}

1) A. Henglein und G.A. Muccini, Z. Naturforschg., 15a, 584 (1960).
2) H. Wänke und H. Hintenberger, Z. Naturforschg., 13a, 895 (1958).

3) T. Hayakawa, H. Hintenberger und H. Wänke, Z. Naturforschg., 16a, 844 (1961).

4) 岡野純，他 5 名，質量分析，No. 15, 16 (1960).

5）後藤正之，他 4 名，質量分析，No. 14，21, (1960).

6) T. Sugiura, Bull. Chem. Soc. Japan, 35, 1257 (1962). 